\title{
New records on the use of man-made constructions as diurnal roosts by bats from the southern Amazon in central Brazil
}

\author{
Camila S. LIMA ${ }^{1,2^{*}}$, Luiz H. VARZINCZAK ${ }^{1,2}$, Rafael de OLIVEIRA ${ }^{1}$, Fernando C. PASSOS ${ }^{1,2}$ \\ 1 Universidade Federal do Paraná, Laboratório de Biodiversidade, Conservação e Ecologia de Animais Silvestres, Departamento de Zoologia, Curitiba PR, 81531-980. \\ 2 Universidade Federal do Paraná, Programa de Pós-Graduação em Ecologia e Conservação, Curitiba PR, 81531-980. \\ *Corresponding author: camila.sdlima@gmail.com
}

\section{ABSTRACT}

Roosts are a key part of bat species' life stories. Information on roost use enables us to understand the biological processes underlying bat ecology and is crucial with regard to the natural-roost loss and environmental pressures related to habitat destruction that has been considered as a threat affecting bat conservation. The aim of this study was to collect new data on the diurnal artificial-roost use by bats in a landscape from the southern Amazon. We observed bat species roosting at an abandoned house in a highly fragmented ecotone between the Amazon and Cerrado biomes. We observed one Trachops cirrhosus individual roosting in physical contact with one Phyllostomus hastatus. One year later, we noticed a compositional change at this roost, in which we found a large colony of Pteronotus parnellii. These findings may shed light on the potential flexibility of the roosting requirements of these species in such landscapes. Moreover, this is one of the first records of the use of human constructions by P. parnelli in such fragmented landscapes, a bat species that until recently was thought of as being associated only with well-preserved natural roosts.

KEYWORDS: Trachops cirrhosus, Phyllostomus hastatus, Pteronotus parnelli, roosting behavior

\section{Novos registros sobre a utilização de construções humanas como abrigos diurnos por morcegos no sul da Amazônia Brasileira}

\section{RESUMO}

Abrigos desempenham um papel importante na história de vida dos morcegos. Informações sobre sua utilização possibilitam a compreensão dos processos biológicos associados à sua ecologia e são cruciais considerando que a perda de abrigos naturais e que as pressóes ambientais relacionadas à descaracterização dos ecossistemas são ameaças para a conservação deste grupo. O objetivo desde estudo foi coletar novos dados sobre a utilização diurna de abrigos artificiais por espécies morcegos em uma região ao sul da Amazônia. Nós observamos espécies de morcegos abrigando uma casa abandonada em uma regiáo ecotonal entre os biomas Amazônia e Cerrado. Neste local, observamos um indivíduo de Trachops cirrhosus em contato físico com um indivíduo de Phyllostomus hastatus. Após um ano, observamos uma mudança neste abrigo, no qual uma colônia de Pteronotus parnellii foi observada. Estes registros podem lançar luz sobre a possível plasticidade destas espécies com relação às suas necessidades para a utilização de abrigos nestas paisagens. O registro trazido aqui é um dos primeiros sobre a utilização de construçóes humanas por $P$. parnellii, uma espécie comumente associada a abrigos naturais e bem preservados.

PalavRaS-Chave: Trachops cirrhosus, Phyllostomus hastatus, Pteronotus parnelli, poleiros artificiais de morcegos. 
Bats are the second mammal speciose order (Wilson and Reeder 2005). This diversity is reflected in the variety of ecological roles they perform, especially regarding their dietary diversification, which includes seed dispersal, plant pollination and insect population control (Patterson et al. 2003).

For bats, roosts play a crucial role in reproduction, hibernation, parental care, protection and intra- or interspecific social interactions (Kunz 1982; Kunz and Lumsden 2003). Bat species are capable of using several both natural and artificial structures for roosting, such as caves, hollows, foliage, mines, shelters and man-made constructions (Bredt et al. 1999; Fenton et al. 2001; Biavatti et al. 2015). Nevertheless, despite this apparent flexibility in roosting requirements, natural-roost loss and environmental pressures owing to habitat destruction and fragmentation have been considered as threats affecting bat conservation globally (Mickleburgh et al. 2002). Consequently, by taking into account the importance of roosts in bats' life history, new data on roost use in such landscapes can help in achieving a better understanding of how bat species respond and adapt to these environments. Furthermore, this information is important for assessing which structures bats utilize and for determining their colony size, as well as knowing which and how many species are found inhabiting and sharing roosts in order to evaluate their interspecific interactions (Costa et al. 2010).

The aim of this study was to collect new data on the natural history aspects of the diurnal artificial-roost use of bat species in a highly fragmented landscape in an ecotone between the Amazon and Cerrado biomes in central Brazil.

As part of a sporadic faunal survey, our observations took place at the Mato Grosso State, central Brazil, in a region between Porto Alegre do Norte and Confresa municipalities $\left(10^{\circ} 37^{\prime} 54^{\prime \prime}\right.$ S, 51 $51^{\circ} 41^{\prime \prime} \mathrm{W}$; Figure 1). This region is classified as Aw in the Köeppen climate classification, with temperature and annual precipitation means of $26^{\circ} \mathrm{C}$ and $2000 \mathrm{~mm}$, respectively (Alvares et al. 2012). Regionally, the landscape is composed of a highly fragmented Amazon forest remnant surrounded by an agricultural matrix with soy cultivation. The region is located in an ecotone (transition zone) between the Amazon forest and the savannas of the Cerrado biome.

We undertook two diurnal visits to an abandoned brick house with an area of approximately 15 square meters and a maximum height of 5 meters. At this house, two species from the Phyllostomidae family (New World leaf-nosed bats) were found. One Trachops cirrhosus (Spix, 1823) individual and one Phyllostomus hastatus (Pallas, 1767) were observed roosting in physical contact with each other (Figure $2 \mathrm{~A}$ ). Approximately one year later, on visiting the house again we noticed that both species were no longer present in that roost. Instead, there was a colony of more than 50 Pteronotus parnellii Gray, 1843 individuals, a Mormoopidae bat species (Figures 2B and 2C).

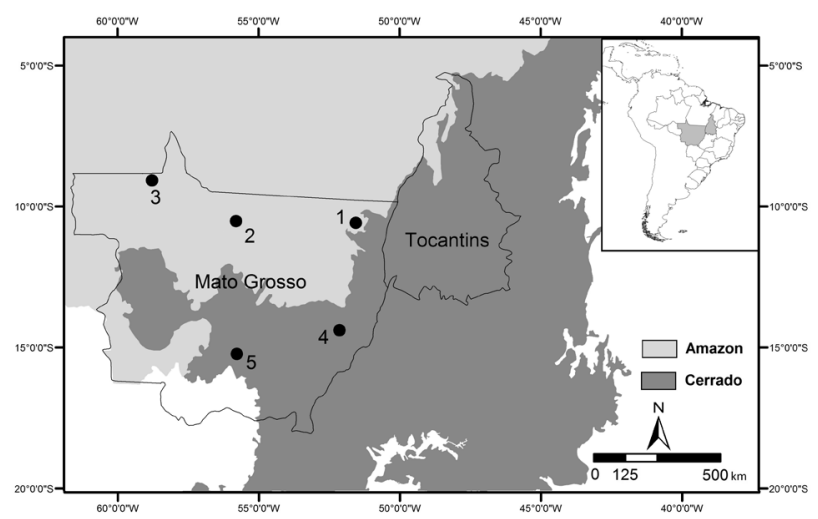

Figure 1. Depiction of the Mato Grosso and Tocantins States, Central Brazil, and the extension of the Amazon and Cerrado biomes. 1: Record from Confresa and Porto Alegre do Norte municipalities (this study); 2 and 3: previous records of $T$. cirrhosus for southern Amazon at the Medium Teles Pires River (Miranda et al. 2015) and Juruena National Park (Dalponte et al. 2016), respectively; 4 and 5: the first formal record of T. cirrhosus for the Cerrado of the Mato Grosso State at the Nova Xavantina municipality (Sousa et al. 2013) and the recent record of this species for the Chapada dos Guimarães National Park (Lima et al. in press), respectively. For details, see the main text.

Despite the presence of adjacent additional buildings, at the time of our visits these had not been utilized as roosts by bats.

Although the cohabitation of T. cirrhosus with $P$. hastatus had been previously reported, such records are from natural and well-preserved roosts and there are few records compared with other species pairs (Bredt et al. 1999). On the other hand, in a large data set compiled for southeastern Brazil (Biavatti et al. 2015), which included a large area of the Atlantic Forest, and which is considered the best sampled region in this country in relation to its bat fauna (Bernard et al. 2011), there were no records of $T$. cirrhosus sharing artificial roosts with $P$. hastatus. Thus, the apparent association between these species in artificial roosts seems to be uncommon, and the information presented here may even be among the first regarding those species sharing roosts in diurnal man-made constructions in Brazil.

Several explanations have been proposed to clarify the patterns of bat species association in roosts. For example, the physical contact among species sharing roosts, as observed here for T. cirrhosus and P. hastatus, could be energetically favorable due to an increase in roost temperature (Kunz 1982). On the other hand, Costa et al. (2010) speculated that such associations between $P$. hastatus and other bat species might be related to a decrease in predation risk, since by delaying their foraging onset and waiting for other species to leave the roosts first, $P$. hastatus would be under a lower risk of attack from predators. However, this is only a hypothesis that can be further tested, and casual associations among species, whether due to convergence on roost requirements (Kunz 


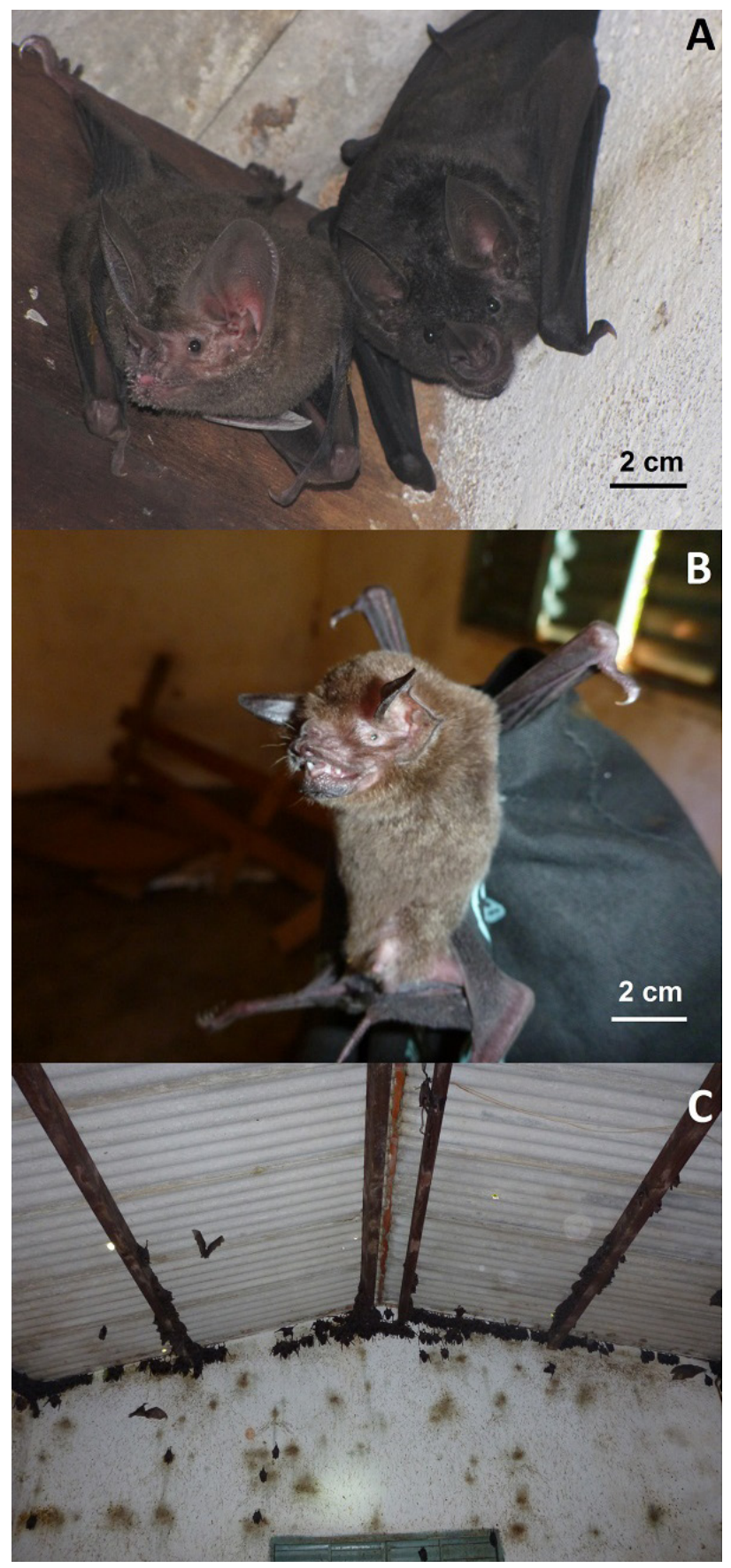

Figure 2. A: Trachops cirrhosus (left) and $P$. hastatus (right) sharing a roost in physical contact in an abandoned man-made construction between Porto Alegre do Norte and Confresa municipalities, central Brazil; B: Pteronotus parnellii roosting at the same roost where $T$. cirrhosus and $P$. hastatus were observed previously; $\mathrm{C}$ : an overview of the $P$. parnellii colony inside the room. This figure is in color in the electronic version.

1982), since both species are from Phyllostominae sub-family and closely related to each other both in terms of their evolution and ecology, or due to the habitat changes in this landscape, cannot be discarded. For example, the largest forest remnants in this region are found approximately $150 \mathrm{~km}$ west of our focal observation. Thus, owing to the high degree of deforestation and fragmentation, bats can simply be forced to occupy artificial roosts as a result of the reduced availability of natural ones.

It is interesting to note the presence of $P$. parnellii in an artificial roost and human construction, since its preference for natural roosts such as humid caves and tree cavities has been widely described in literature (Herd 1983; Fenton et al. 2001). Its occurrence in an artificial roost in a disturbed landscape, as well as its recent record in urban areas (Silva and Anacleto 2011), can help us to understand both the species' requirements and flexibility for its occurrence and persistence in such habitats. Moreover, it is worth noting the compositional change at the roost between our two focal observations. While T. cirrhosus does not show roost fidelity (Kalko et al. 1999), P. hastatus seems to behave in the opposite way (Pacheco et al. 2010). However, we do not have additional data to explain this change, since we did not perform continuous observations at this roost. This is also valid for the fact that both species had been found living in large groups including dozens of individuals (Cramer et al. 2001; Santos et al. 2003), while here they were found alone.

In addition to the roost information, we present here a geographic note on the distribution of T. cirrhosus in both the Amazon biome and Mato Grosso State. In spite of being considered of broad geographical distribution, the first formal record of this species for the Mato Grosso State took place only in 2013 (Sousa et al. 2013). Since then, its geographical distribution has been extended to new localities in this state (Miranda et al. 2015; Dalponte et al. 2016; Lima et al. in press). Together with Miranda et al. (2015), the occurrence of T. cirrhosus between Porto Alegre do Norte and Confresa municipalities is the southernmost record of this species for the Amazon, a distance of roughly $500 \mathrm{~km}$ east of the record at the Medium Teles Pires River. Considering the vegetational similarity and the short distance (Figure 1), this record therefore opens up the possibility of the occurrence of this species in Tocantins State where the species have never been recorded, since their flight capabilities has enabled bats to overcome geographical barriers, allowing them to make long-distances dispersal (Sousa et al. 2013; Arnone et al. 2016).

With regard to the role of bats in the maintenance of ecological processes and ecosystem functioning, as well as the pressures they suffer owing to environmental changes, information on the natural history of bat species roosting behavior and their requirements is important due to the anthropogenic changes imposed on natural landscapes. Along with complementary studies, this kind of data might be useful to enable understanding of the responses of bat species in such a changing environment. 


\section{ACKNOWLEDGEMENTS}

The authors are grateful to Coordenação de Aperfeiçoamento de Pessoal de Nível Superior for the scholarships provided to C.S.L. and L.H.V., and to Conselho Nacional de Desenvolvimento Científico e Tecnológico for a grant to F.C.P (number 303757/2012-4) and a scholarship provided to R.O. The authors are also grateful for the comments from editors and anonymous reviewers.

\section{REFERENCES}

Alvares, C.A.; Stape, J.L.; Sentelhas, P.C.; Gonçalves, J.L.M; Sparovek G. 2012. Köppen's climate classification map for Brazil. Meteorologische Zeitschrift, 22: 711-728.

Arnone, I.S.; Trajano, E.; Pulchério-Leite, A.; Passos, F.C. 2016. Long-distance movement by a great fruit-eating bat, Artibeus lituratus (Olfers, 1818), in southeastern Brazil (Chiroptera, Phyllostomidae): evidence for migration in Neotropical bats? Biota Neotropica, 16: e0026.

Bernard, E.; Aguiar, L.M.S.; Machado, R.B. 2011. Discovering the Brazilian bat fauna: A task for two centuries? Mammal Review, 41: 23-39.

Biavatti, T.; Costa, L.M.; Esbérard C.E.L. 2015. Morcegos (Mammalia, Chiroptera) em refúgios diurnos artificiais na região sudeste do Brasil. Mastozoología Neotropical, 22: 239-253.

Bredt, A.; Uieda, W.; Magalhães, E.D. 1999. Morcegos cavernícolas da regiáo do Distrito Federal, centro-oeste do Brasil (Mammalia, Chiroptera). Revista Brasileira de Zoologia, 16: 731-770.

Costa, L.M.; Lourenço, E.C.; Esbérard, C.E.L.;Silva, R.M. 2010. Colony size, sex ratio and cohabitation in roosts of Phyllostomus hastatus (Pallas) (Chiroptera: Phyllostomidae). Brazilian Journal of Biology, 70: 1047:1053.

Cramer, M.J.; Willig, M.R.; Jones, C. 2001. Trachops cirrhosus. Mammalian Species, 656: 1-6.

Dalponte, J.C.; Gregorin, R.; Esteves-Costa, V.; Rocha, E.C.; Marcelino, R. 2016. Bat survey of the lower Juruena River and five new records for the state of Mato Grosso, Brazil. Acta Amazonica, 46: 227-232.

Fenton, M.B.; Bernard, E; Bouchard, S.; Hollis, L.; Johnston, D.S.; Lausen, C.L.; Ratcliffe, J.M.; Riskin, D.K.; Taylor, J.R.; Zigouris, J. 2001. The bat fauna of Lamanai, Belize: Roosts and trophic roles. Journal of Tropical Ecology, 17: 511-524.

Herd, R.M. 1983. Pteronotus parnellii. Mammalian Species. 209: 1-5.
Kalko, E.K.V.; Friemel, D.; Handley, C.O.; Schnitzler, H.U. 1999. Roosting and foraging behavior of two neotropical gleaning bats, Tonatia silvicola and Trachops cirrhosus (Phyllostomidae). Biotropica, 31:344-353.

Kunz, T.H. 1982. Roosting ecology of bats. In: Kunz, T.H. (Ed.). Ecology of Bats. Plenum Press, New York, NY, p. 1-56.

Kunz, T.H.; Lumsden, L.F. 2003. Ecology of cavitiy and foliage roosting bats. In: Kunz, T.H.; Fenton, M.B. (Ed.). Bat ecology. University of Chicago Press, Chicago, IL, p. 3-89.

Lima, C.S.; Varzinczak, L.H.; Passos, F.C. In Press. Richness, diversity and abundance of bats from a savanna landscape in central Brazil. Mammalia, in press. DOI: 10.1515/mammalia-2015-0106. Published online first: January 21, 2016.

Mickleburgh, S.P.; Hutson, A.M.; Racey, P.A. 2002. A review of the global conservation status of bats. Oryx, 36: 18-34.

Miranda, J.M.D.; Zago, L.; Carvalho, F.; Rubio, M.B.G.; Bernardi, I.P. 2015. Morcegos (Mammalia: Chiroptera) da região do Médio Rio Teles Pires, Sul da Amazônia, Brasil. Acta Amazonica, 45: 89-100.

Pacheco, S.M.; Sodré, M.; Gama, A.R.; Bredt, A.; Cavallini, E.M.; Marques, R.V.; Guimarães, M.M.; Bianconi, G. 2010. Morcegos urbanos: Status do conhecimento e plano de ação para a conservação no Brasil. Chiroptera Neotropical, 16: 629-647.

Patterson, B.D., M.R. Willig and Stevens, R.D. 2003. Trophic strategies, niche partitioning and patterns of ecological organization. In: Kunz, T.H.; Fenton, M.B. (Ed.). Bat ecology. University of Chicago Press, Chicago, IL, p. 536-579.

Santos, M.; Aguirre, L.F.; Vázquez, L.B.; Ortega, J. 2003. Phyllostomus hastatus. Mammalian Species, 722: 1545-1410.

Silva, S.G.; Anacleto, T.C.S. 2011. Diversidade de morcegos entre áreas com diferente grau de alteraçáo na área urbana do município de Nova Xavantina, MT. Chiroptera Neotropical, 17: 1003-1012.

Sousa, R.F.; Venere, P.C.; Faria, K.C. 2013. Bats in forest remnants of the Cerrado savanna of eastern Mato Grosso, Brazil. Biota Neotropica, 13: 236-241.

Wilson, D.E.; Reeder, D.M. 2005. Mammal species of the World: a taxonomic and geographic reference. 3rd ed. The John Hopkins University Press, Baltimore, MD, 2142p.

Received: 18/05/2016

Accepted: 25/07/2016 